\title{
Imaging Cities; Social Perception and Physical Composition; Case study of Pettah, Colombo
}

\author{
Anoj Dhananjaya Pathinayaka ${ }^{1,}$, Janaka Wijesundara ${ }^{2, b}$ \\ ${ }^{1}$ Post Graduate Student- Master of Urban Design, Dept. of Architecture, \\ University of Moratuwa, Sri Lanka \\ ${ }^{2}$ Senior Lecturer, Dept. of Architecture, University of Moratuwa, Sri Lanka \\ anojpathy@gmail.com, bjawij@yahoo.com,
}

\begin{abstract}
Today, it is seen that many cities in South East Asia are undergoing a rapid urban metamorphosis and transforming their physical compositions based on spatial and land use practices to fit to the globalization trends. Recent trends of promoting a city as a unique place have engaged in re-emerging their own city images. Under these concerns, both the physical and the social environments of cities are to be treated as a combined entity in strengthening the city image.
\end{abstract}

The study explores the makeovers in urban built environments discussing changing morphological patterns due to the urban transformation and planning interventions in urban settings (places) studying Pettah in Colombo City as a case. The research aims to inspect the social perceptions of such urban environmental trends assessing the city/place image. The social responsive study is analyzed with field investigation data of physical composition of the built environment of the selected case. A literature survey on corresponding urban studies figures out the parameters effective on the research, and the observations and findings through the questionnaires reinforces the final assessment and the discussion.

The research confirms that the social perception of a city image is strongly attached to the parameters of number of key social factors and physical factors. A creative composition of these two elements brings positive results in imaging cities/places and the parameters for the relationship of social perceptions and physical composition will be revealed.

Keywords: Social Perception, City/place Image, Physical Composition, Pettah, Colombo. 
International Journal on Urban Environments

\section{Introduction}

Urban settings today go through significant transformations as has never happened before in most of the South East Asian countries and also in many other developing countries. But unfortunately, majority of these urban settings are inadequate for the increasing number of population. This nature is highly visible in Sri Lankan context and almost all the commercial cities of the island are seriously suffering from overcrowding. As a solution, all efforts have been taken to optimize land use and infrastructure facilities and other amenities for future developments in many developing cities (Barnett, 1982; Prabhakar, 1978).

Generally, cities are specially planned to enhance the functionality and they are proposed to be well balanced in civic activities, commercial activities and recreational activities. Further, they are responsible for building up community relationships as well as public convenience. To achieve such a favorable environment there should be a balanced built environment to maintain a certain pattern in a city which can produce a good city image. As Lynch said, "every citizen has had long associations with some part of his city, and his image is soaked in memories and meanings" (Lynch, 1960;1).

People always connect themselves to their immediate surroundings and automatically keep some important associations in mind to recall from the particular surrounding. But this human nature has been disturbed due to many circumstances of the current development trends. In contemporary cities, identity of a place is hard to come by and is often changed. People cannot relate themselves to the street edges or the buildings because the entire city is changing rapidly. Due to these changes in physical composition of the city, public convenience is being eroded (Lynch, 1960; Day, 2002).

Based on the above concerns, this study is driven on an inspection of the social perception of urban environmental trends assessing the city/place image with special reference to selected places in Pettah, Colombo, which is the busiest commercially provoked urban setting in Sri Lanka. This evaluation will be useful in further city planning procedures since it proposes criteria on imaging cities through a creative composition of physical and social contexts to reach the goal of sustainability in urban transformations.

The focuses on morphology, in relation to urban transformation and planning and aims to re-examine identity and sense of a place in transforming urban settings to figure out the enhancement given to its city/place image. The study examined 5 identified places in Pettah to harness qualitative data and information and projects the scenario for the larger region of Pettah.

\section{Places, Urban built environment and its transformation:}

A place is a thoughtful entity characterized by cultural and human aspects of physical space. Tranick "This character consists both of concrete things having material substance, shape, texture, and color and of more intangible cultural associations, a certain patina given by human use over time" (1986; 113). He further explains that even though a place is unique there may be physically same boundaries (1986). The term place derives its uniqueness through its cultural content. It is the appreciation of such physical space by a group or groups of people. Relph $(1976 ; 3)$ declares that "a place is 
International Journal on Urban Environments

not just the 'where' of something; it is the location plus everything that occupies that location seen as an integrated and meaningful phenomenon".

Inhabitants of a place become more settled over the time. Consequently the human settlements convert into compact living ranges which are not sufficient to fulfil all the needs and wants of people. Referring to the historic backgrounds, it is clear that folks settled with agricultural base and eventually it was controlled with trade activities and at the end of the day it was transformed into an industrial base with lot of opportunities in employment opening out the new world implications. "The new urban settlement is created to control some resource, or to relieve overpopulation at home" (Lynch, 1984; 16). This is how Lynch (1984) has seen the urban settings a long time ago. But the fast growth of people never stopped there and the rapid improvement of industrial activities also happened subsequently.

Further, Smith $(1988 ; 8)$ describes that "a process of growing population concentration whereby the proportion of the total population which is classified as urban increasing". According to him, where an increasing population lives becomes an urban settlement or an urban setting.

Development is a concern of all the countries to move onwards in terms of social, economic, cultural, and technological approaches, etc. (Chadwick, 1987; Yang, 2010). So a considerable urban change over time with large scale urban development and revitalization programs or supplementary adjustments in belonging culture and urban life of local setting is considered as the 'urban transformation' and it is a long-term changing process of an urban setting, with the attentiveness between social and spatial structures (Yang, 2010).

During the process of urban transformation, physical change of the relevant area becomes an important factor. In its simplest idea, physical transformation is the change or the advancement of the built environment that can be seen over time. Alternative systems of construction methods and alterations for the elements of the built setting can be noticed during such transformation. Physically one or two key buildings which are historically important or any other valued reference will be preserved as a focal point or a major component. Then the rest of the area will be filled with lots of accommodation units for different functions. Sometimes these areas will be restored with very tall buildings providing more floor area to attract more commercial value. At this point the term city/place image becomes more important because all these enhancements shall be effective on preserving the unique character of the built environment because the social representation of the particular area cannot be ignored. It is the live wire of the place.

\section{City image as a creative composition}

Cities have become cities because of the people and their activities. This can be called social structure. To facilitate those people and their needs the built environment has been designed and casts the city form as the ultimate result. Accumulation of this built form and social structure defines the city image which is intangible and it exists in human minds. 
Kevin Lynch states (1960) that imageability is a high probability of the quality of a physical object that evokes a strong image on its observer. It is a notable change from its immediate context like an object coming out from a fabric. Either this can be a special building or a landmark exaggerated from the city or a certain pattern of such buildings and landmarks accumulatively exaggerated the city itself from the immediate or other competing cities. So the city image is the outlook that people memorized according to a certain city which is mainly based on its built environment. The built setting is the most important element in city scape because it has a strong power to convert and reform the life setting and define activities responding to its form.

Rapoport (cited in Jagadisan et al, 2010) also argues for the need to conceptualize 'environment' in general, and to consider types of environments. So that the environment or the settlement can be understood as;

- the organization of space, time, meaning, and communication;

- a system of settings;

- the cultural landscape;

- a consisting of fixed, semi-fixed, and non-fixed elements.

With the time a space develops serving its stake holders. Eventually a comprehensive series of activities can be seen that renders a significant understanding about the area. This communicative value is the statement or the expression of relevant space. To keep an appropriate communication, it needs a system of settings.

Trancik (1986) mentions that composition of the above components of built environment should be controlled carefully and consciously catering following key aspects to form the city.

- The two-dimensional pattern

- The three-dimensional frame

- The placement of objects(buildings) of an urban setting

With an eye on Halprin's (1972) works, physical space is generated through static or stable, temporary and movable components in a socio-economic and socio-cultural process. Therefore the research discusses the case study through following components of urban built environment.

Permanent Structures - Permanent components that boundary an urban setting, are built with more stable materials such as concrete, steel and brick with distinct characters or styles. The function and co-related activities combined to these built fabric are fixed, and they cannot be changed overnight.

Temporary Structures - These structures are not fixed in the setting and built out of light-weight materials. Mostly they are required to meet some functional necessities mostly for a certain period of time such as during special religious festivals, seasonal celebrations, etc.

Mobile Structures - According to Rahul Mehrotra (2008) kinetic activities focus on to the gaps of the major activities accommodated in permanent and temporary structures. Most of these informal activities run on mobile structures that ease the movement of goods in place to place. In a broader perspective these mobile structures are the driving force of 'life' of an urban setting.

Open Spaces - Aforesaid components of an urban setting become the basic factors to outline the voids or the open spaces in the setting. These spaces are the non-built plots 
International Journal on Urban Environments

of land. Either they are defined not to be built in order to keep green spaces or they are still not taken into consideration to put up buildings.

The presence of above mentioned main components creates the secondary elements of built environment which is socially attracted and experienced as a whole city. According to Kevin Lynch (1960), they are Paths, Edges, Nodes, Districts and Landmarks. Lynch describes that paths are elements which carry activities and movement of people like roads, railroads and canals etc. Edges can be defined as boundaries between two segments, linear breaks in continuity: shores, beaches, railroad cuts, edges of development and walls and the nodes are the connection points in cityscape where districts are large scale built form sections. Landmarks are the point references in the built environment.

\section{Social perception of a city}

Considerations on cities significantly attached with the social attributes of a city which is greatly effective on the city image, because city image transpires in the minds of people who experience that particular city. So the perception of the people defines the city image. And also people consider city as a place. And the city is a wise entity characterized by aspects of human culture, social space and physical space. Further, social involvement in the place is an essential factor in urban design also, because the places are for people. Kevin Lynch advocates "We must see any place as a social, biological, and physical whole, if we mean to understand it completely" (1984;48). So the perception of people on city always refer three main factors which are the concerns of people about a place, city or a building. These three factors can derive the perception or the sensitivity of people on a city.

\section{Identity of a place}

An identity is a kind of recognition. A place as a unique entity there is an exact recognition. The physical components of an object render its identity. "We recognize the identities of people, plants, places and even nations" (Relph, 1976;45). When the identity of a place is taken into consideration there are physical components but people look at it differently. They may see many of the components but they define a place with their experience, feeling and attitude.

\section{Memory of a place}

Memory is the information that a person keeps with him about a person, place or a city. When a person experiences a city or a place mainly for the first time, some qualities and characteristics are unconsciously recorded in his mind and that person reminds and describes about the particular place or a city with that recorded characteristics and memory. A city or a place can be memorized by the physical settings and also the social setting or activities and functions which are unique to the particular city. And some people who experience the city in their day to day life memorized the city referring more personal bias. Like traveling places, working places and passing 
elements. In advanced situations some cities get memorized referring special built environment elements such as Monuments and Landmark buildings. So the memorability of the building setting should be stronger enough to enhance the image of the city and its uniqueness (Lynch, 1960; Relph, 1976).

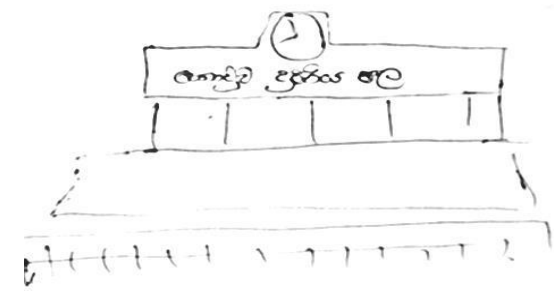

Fig. 1: Imagery of Pettah - the memory of Built Environment, Sketch by a Participant in the Research Source: author

\section{Sense of place}

Relph (1976) states "Yet, however we feel or know or explain space, there is nearly always some associated sense or concept of place". Sense is all combined with the experiences of the place or city. This is the most important attribute of the social composition of a city, because above discussed identity and the memory always based on how people experience the city and human scale is very much effected to the sense. To experience a place or a city it should be in a capable range for people to feel comparing to human dimensions.

Kevin lynch (1960) reviews and discusses that the visual sensation of shape, color, texture, motion or polarization of light and also senses like sound, touch, smell, and sense gravity and kinesthesia are contributed to identify the place and environment and also that all should be in a range that observer can practically experience. For a better city image sensibility of the city should be sound for people. Actually it is the ultimate social sensitivity or the social perception on a city or a place. Gordon Cullen $(1995 ; 11)$ also strengthens this argument by saying colours, textures and scales are very significant characteristics of places that people experience. Then they get the impressions of the architectural styles of the built environment. Finally they relate themselves into it; emerge a personality. They see the uniqueness of the place. To enable such procedure the built environment should have a balance and an order. Otherwise people do not experience such places.

\section{Case study analysis - Selection of case study}

The study is focused on urban settings which are being transformed and already transformed responding to the urbanization. Social perception of a place as a physical composition in terms of identity, memory and sense of place is the major concern of this research. Pettah in Colombo; the busiest commercial area of the country which has historic backgrounds was selected as a case to support this research.

Pettah, Colombo 
International Journal on Urban Environments

Before Colombo becoming the commercial capital of the country, Pettah area had lots of administrative bodies. Eventually Pettah got developed with compressed trade and other commercial activity concerns. Some parts of Pettah are already transformed and some are currently transforming. With this development, transportation systems of the area became notably important. Becoming a transportation node by establishing Fort railway station, Gunsinghepura bus station and Bastian Mawatha bus station, commuters and outside daily customers become a major component in Pettah in participating trade activities and business management and commercial administration activities. The Main Street, Sea Street and Olcott Mawatha are the important roads that ensures circulation through the area.

Due to the administrative bodies shifted to Sri Jayewardenepura Kotte, the built pattern of this setting got affected. Currently some of the façades are disappearing and covering by the huge constructions as well as temporary integrations to facilitate different types of commercial activities. So Pettah as the busiest urban setting which is attracted by each and every person who visits Colombo furnishes this research providing a lot of conforming information and data.

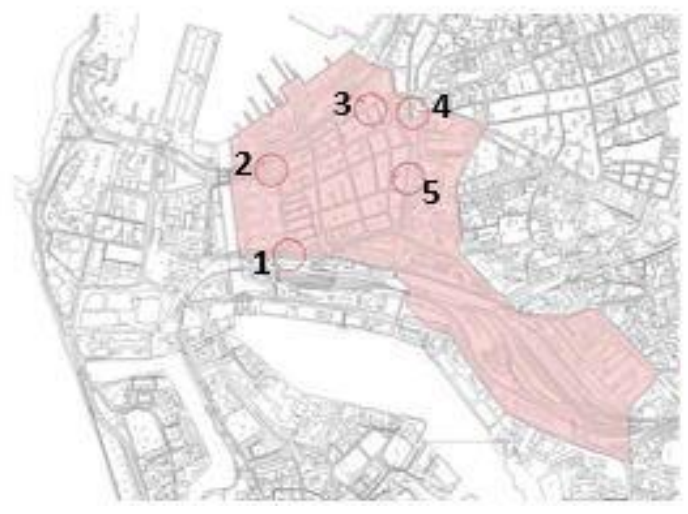

Fig. 2: Pettah in Colombo

Source: Survey Department of Sri Lanka

Pettah area is highlighted in this map of Colombo and the circled areas are the selected places for the study. These places numbered as "place 1" to "Place 5" are used in the main assessment.

1) Malwaththa Road entrance from Olcott Mawatha

2) Khan clock tower

3) St. John's Fish market converting into a Gold market

4) Gaswork Junction with Bell tower

5) Bodhiraja Mawatha

Many interviews were conducted by the author in preliminary stages of this study as a pilot survey to identify the major aspects of public considerations.

The only identity that people have today is Pettah is full of shops, which is very true but, at the same time there are lots of interesting and historically valued places in the same setting. With the development, the owners of these buildings have modified their property to meet a maximum commercial arrangement rather than appreciating such 
International Journal on Urban Environments

important buildings. Therefore the Identity, Memory and the Sense of place are not ensured in this context which creates a negative impact on its own city/place image.

\section{Framework for the analysis}

- During the study on components of selected places several pilot surveys were carried out to figure out the special key aspects of relevant places.

- Both Physical characteristics and Cultural characteristics are supported by the observations and photographic surveys.

- Relevant information and data collected from the particular authorities.

- Both formal and informal interviews reinforce the social perception on the selected places.

The questionnaire and the imagery survey sessions were conducted on 2 days for 400 people. After the pilot surveys, the questionnaire and the imagery survey were carried out among 200 people per day at selected 5 places ( 40 people each). There were 2 complete rounds from place 1 to place 5 interviewing 20 people at each place to cover 200 people. After the interviewing sessions on day 1, thorough observation, photographic and personal communication sessions were carried out for continuous 12 days and again the interviewing sessions for the remaining 200 people were carried on the 14th day following the day 1 process. Personal communications aided the observations towards more practical situations.

\section{Analysis}

1) The links of identity, memory and sense of place with the components of urban settings, physical characteristics and social characteristics.

a) Identity of a place occurs with the components of that place. Permanent structures become the most important built component because most of the times a static building or couple of buildings cast an identity to the particular place. Sometimes temporary structures also create an identity of a certain place. As discussed in the previous sections a change in a typical layout/building fabric becomes an eye catching point and it depicts the identity.

b) Memory and sense of place directly link with the physical composition of that place - Spatial Anthropology analysis.

c) Identity, memory and sense of place become more strong and meaningful with the social representation - Social Anthropology analysis.

This analysis contains a lot of data in tables with particular photographic surveys of each selected place (place 1 to 5) and based on those analysed data and information, the research proceeded to the analysis part 2 to figure out the sensitivity of each place for its own place image. At this point the research links with Kevin Lynch's (1984) good city form theory, because the research has found that the 5 performance dimensions of good city form theory can be related with the data variables which were used in the analysis 
International Journal on Urban Environments

part 1 as components and elements of places/cities. Therefore the following data analysis supports the research to evaluate the level of sensitivity of physical composition for imaging places/cities.

2) Assessment on place sensitivity - evaluation chart

Kevin Lynch's (1984) 5 performance dimensions of Good City Form theory is used as the basis to design this evaluation chart of the place sensitivity that can be used to assess social perception on physical composition of a place/city towards the place/city image.

Table 1: Place Sensitivity Evaluation Criteria for Pettah, Colombo

\begin{tabular}{|c|c|c|c|c|c|}
\hline & \multicolumn{5}{|c|}{ Comments for the Places } \\
\hline Data Variable & Place 1 & Place 2 & Place 3 & Place 4 & Place 5 \\
\hline Safety & Enabled & Enabled & Partial & Enabled & Enabled \\
\hline Comfort & Satisfied & Satisfied & No & Barely & No \\
\hline Traditions & Dynamic & Unique & Absent & Dynamic & Dynamic \\
\hline Permanent structures & $\begin{array}{l}\text { Average } \\
3 \text { floors }\end{array}$ & $\begin{array}{l}\text { Average } 2 \\
\text { floors }\end{array}$ & $\begin{array}{l}\text { Average } 3 \\
\text { floors }\end{array}$ & $\begin{array}{l}\text { Average } 4 \\
\text { floors }\end{array}$ & $\begin{array}{c}\text { Single } \\
\text { story }\end{array}$ \\
\hline Temporary structures & Many & Few & Many & Many & Many \\
\hline Mobile structures & Many & Few & Few & Many & Absent \\
\hline Open spaces & $\begin{array}{c}\text { Few \& } \\
\text { busy }\end{array}$ & Few & Many & $\begin{array}{c}\text { Few \& } \\
\text { Busy }\end{array}$ & No \\
\hline Legibility & Satisfied & Satisfied & Barely & No & Satisfied \\
\hline Accessibility & High & High & High & High & High \\
\hline Archeological history & $\begin{array}{c}\text { Not } \\
\text { available }\end{array}$ & available & $\begin{array}{c}\text { Not } \\
\text { available }\end{array}$ & available & $\begin{array}{c}\text { Not } \\
\text { available }\end{array}$ \\
\hline Architectural heritage & $\begin{array}{l}\text { Disapp- } \\
\text { aring }\end{array}$ & $\begin{array}{c}\text { Remai- } \\
\text { ning }\end{array}$ & $\begin{array}{c}\text { Conver- } \\
\text { ting }\end{array}$ & $\begin{array}{c}\text { Remai- } \\
\text { ning }\end{array}$ & No \\
\hline Landscape, landmarks & $\begin{array}{c}\text { Highly } \\
\text { available }\end{array}$ & $\begin{array}{c}\text { Highly } \\
\text { available }\end{array}$ & available & available & $\begin{array}{c}\text { Highly } \\
\text { available }\end{array}$ \\
\hline
\end{tabular}

The data variables used above are defined as follows.

Safety - Crime state of the study area.

Comfort - Physical and psychological ease and convenience.

Traditions - Traditions of public social life, civic traditions, festivals and rituals

Permanent structures - Buildings located in relevant study area. These structures will not be taken down completely but will face slight changes in particular developments.

Temporary structures - These are temporary attachments to the aforesaid mass buildings or temporary huts and other structures which are static for a considerable period of time.

Mobile structures - Movable structures in focused areas which are mainly used in commercial based activity like mobile vending.

Open spaces - Spaces that are not concreted with above mentioned 3 factors.

Legibility - Ability to read and understand physical composition. 
International Journal on Urban Environments

Accessibility - Entry points to particular study area.

Archeological history - The value of historic reference

Architectural heritage - Importance of different built styles

Landscape, Landmarks

Comments for the each place on the respective data variables are given 'colour grading' as follows.

\begin{tabular}{rlr}
\hline & Good & $100 \%$ \\
- & Average & $50 \%$ \\
- & Poor & Nil
\end{tabular}

With the above table the research analyses the sensitivity through several charts and graphs. Above grading is offered to come to a numerical state for the qualities of the listed factors. According to the colour grading system sensitivity is clarified by the total sum of percentage for 12 data variables divided by 12 (the average percentage is used).

Finally the research evaluates the sensitivity of Pettah as a whole with the average percentages calculated for 5 particular places which is a projection for the case study.

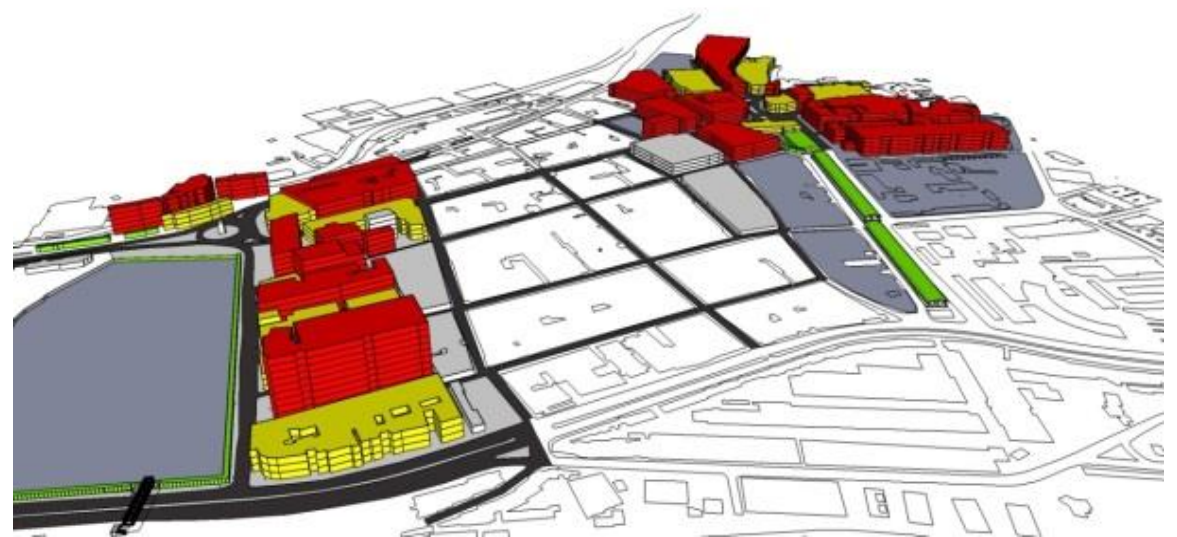

Fig. 3: Building Height Colour Grading for Selected 5 Places

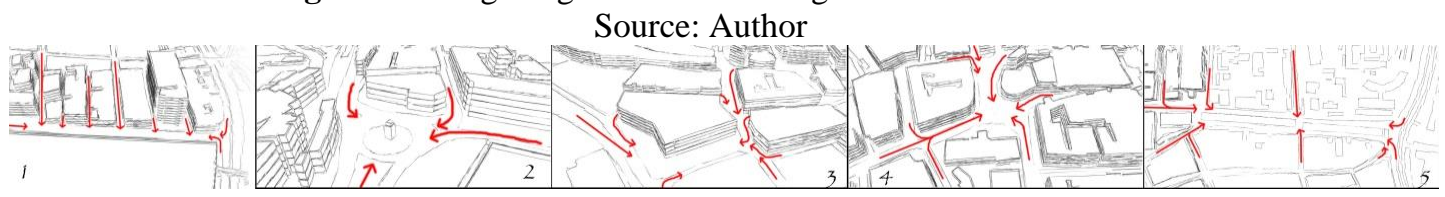

Fig. 4: Accessibility Maps for Selected 5 Places

Source: Author 
International Journal on Urban Environments

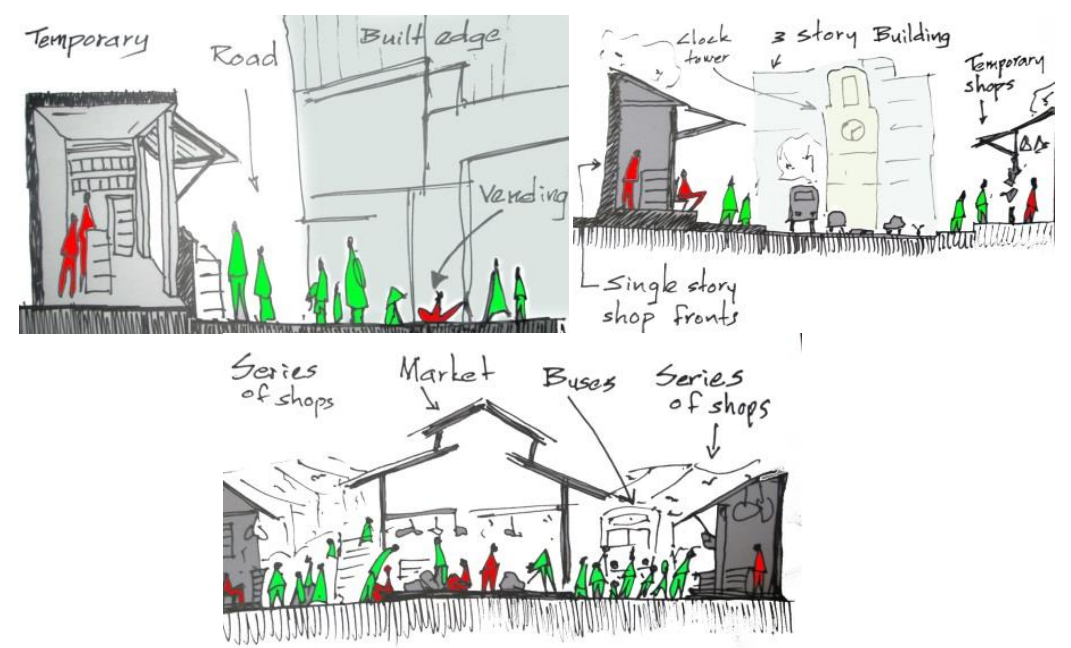

Fig. 5: Some of the Cross Sections to Elaborate the Characteristics of Functioning in Pettah, Colombo

Source: Author
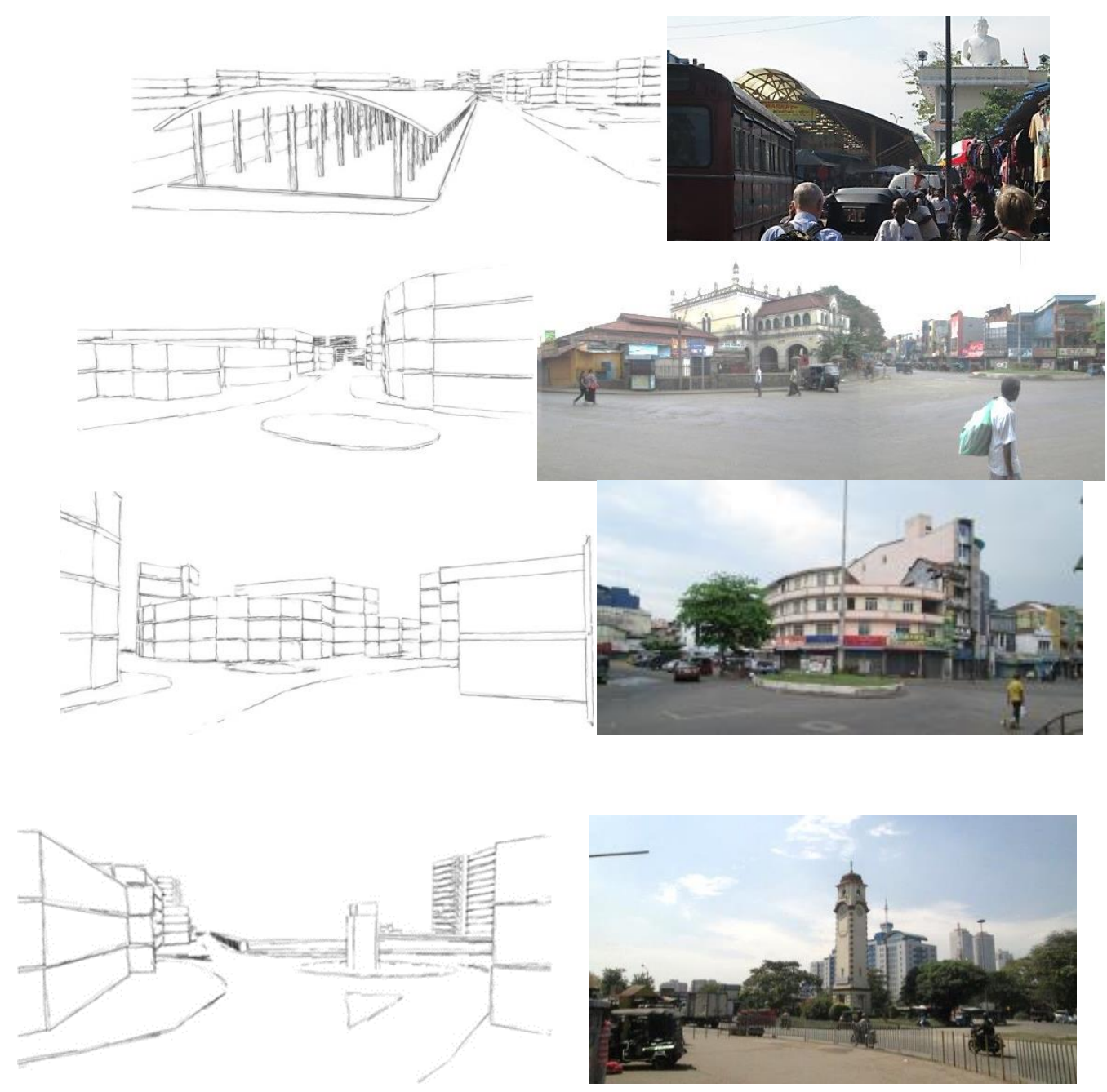


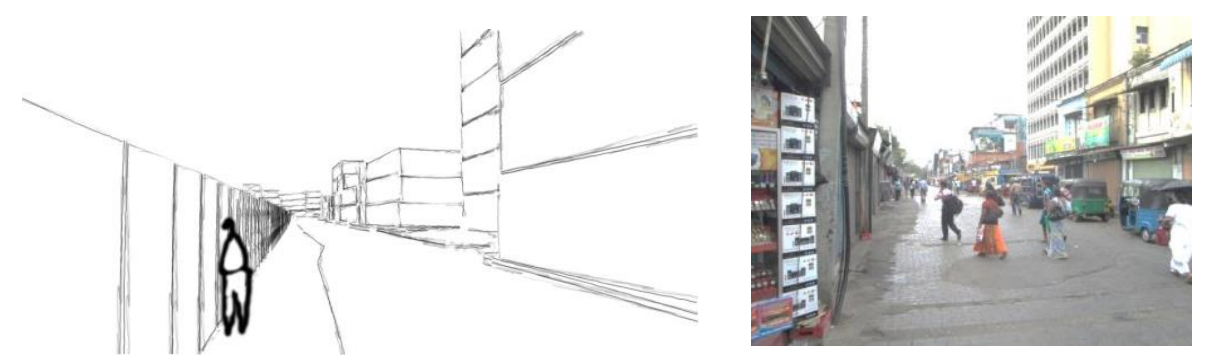

Fig. 6: Personalization of the block models Source \& photo credit: Author

\section{Remarks and comments}

a) Fast growing informal commercial activities tend to overflow the stagnant city form of Pettah.

b) Identical building forms and historically valued buildings are being covered by large hoardings and temporary and mobile structures.

c) Huge vehicular movement has become an obstacle to the pedestrians and it is emerging a character of insecure.

\section{Findings}

a) Social participation always figures out options to face issues come out from the particular urban setting.
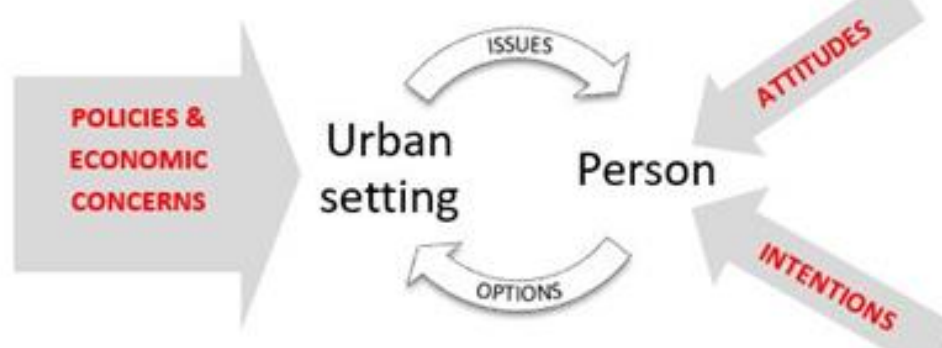

b) Considered urban setting is always personalizing.

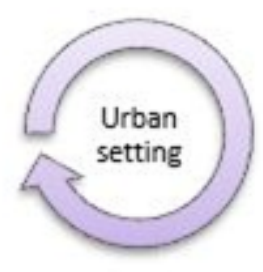


International Journal on Urban Environments

\section{Conclusion}

Generally a place is a combination of fixed, semi-fixed and non-fixed elements located in an open space. A combination of many places can form a setting or a territory which leads the development to an ultimate goal of a city. Developments can be taken into consideration according to its physical composition which should be followed by the social sensitivity, because places or cities are for people. Therefore people who experience these places/cities should be satisfied with the facilities and its ambiance. Then there should be a balance in creating this physical structure and there should be elements that become objects from the built fabric for people to focus and relate themselves in the context. Therefore an identity of a place should be provided enabling people to make memories over that. To welcome more people to achieve publicness and the livability, the particular place should have been planned in a sensible way. The live wire of any given place is the participation of people. It is a global phenomenon.

This development process does not stop at that achievement of providing facilities, knowingly or unknowingly the places/cities compete with each other. So they have to keep unique memories in human mind. Basically that is what meant by image of cities/places. The process of being memorable is defined as the imaging cities/places. So the social perception on physical composition is the main aspect that matters in creating a place/city image. Therefore the cities have to follow a creative composition of physical structure and social structure to enable a positive social perception on its physical composition.

For an analysis like this having only 1 fact to be analysed, $50 \%$ can be taken as the neutral position and $0 \%-49 \%$ can be referred as negative representation where $51 \%$ $100 \%$ can be referred as positive representation of the considered fact. Therefore this criteria can be used to compare 2 or more places/cities in terms of their imageability and it can be used as a self-assessment of its own position in sensitiveness to the people who experience that city or the place. So the development procedures can use this criteria as a tool to figure out their level of sensitivity to create a good city/place image.

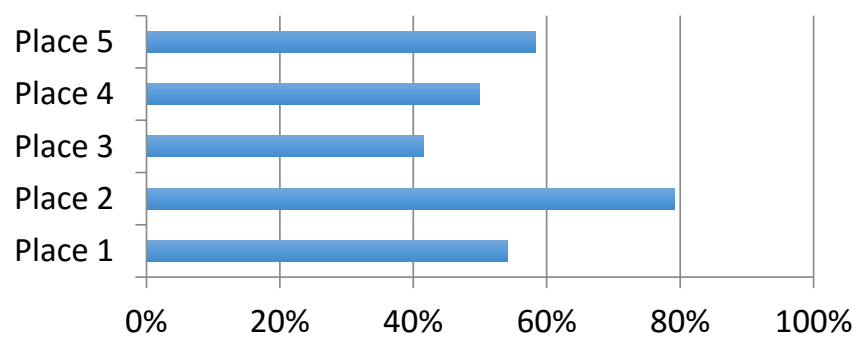

Fig. 7: Place Sensitivity Evaluation among Selected 5 Places Source: author 
International Journal on Urban Environments

Above chart shows that Place 2 is more sensitive for people in keeping a memory through the identity of that place. On other words the imageability of that area is high. Again Place 3 is very low in sensitivity which is a negative impact on keeping a memory. That means that place is losing its own place image.

According to the data taken from above chart the projected sensitivity for whole Pettah comes to a value of $56.65 \%$ which is on the positive side but closer to the neutral position. Therefore it identifies that development of Pettah should give more prominence to the 12 data variables of this evaluation criteria to enhance the physical composition of the area in order to maintain a unique city/place image.

\section{References}

Barnett, J. 1982. An Introduction to Urban Design. New York: Harper \& Row.

Chadwick, G. F., 1987. Models of urban and regional systems in developing countries: some theories and their application in physical planning. Oxford; New York: Pergamon Press.

Cullen, G., 1995. The concise townscape. Oxford; Boston: Butterworth-Heinemann.

Darwin, C., 1859. On the origin of species by means of natural selection, or, the preservation of favoured races in the struggle for life. J. Murray.

Day, C., 2002. Spirit \& Place: Healing Our Environment, Healing Environment, Architectural Press.

Halprin, L., 1972. Cities. Mit Press.

Jacobs, A. B., 1995. Great streets. Cambridge, Mass.: MIT Press.

Jagadisan, S., \& Fookes, T. W., 2010. Extending the ekistic elements: environment-behaviour studies \#1: selected core ideas (Research memorandum No. 10/2). Auckland: Ekistics Research Unit Auckland.

Landry, C., Greene, L., Matarasso, F., \& Bianchini, F., 1996. The art of regeneration: urban renewal through cultural activity. Stroud: Comedia.

Lynch, K., 1960. The image of the city. Cambridge, Mass.: MIT Press.

Lynch, K., 1984. Good city form. Cambridge, Mass.: MIT Press.

Madanipour, A., 2003. Public and private spaces of the city. London; New York: Routledge.

Mehrotra, R., 2008. Negotiating the static and kinetic cities, emergent urbanism in Mumbai. In A. Huyssen (Ed.), Other cities, other worlds: urban imaginaries in a globalizing age (p. 338).

Neuman, M., 2005. The compact city fallacy. Journal of Planning Education and Research, 25(1), 11-26. doi:10.1177/0739456X04270466

Prabhakar V. B., 1978. Ancient and mediaeval town-planning in India. Sagar Publications

Relph, E. C., 1976. Place and placelessness. London: Pion.

Smith, D. D., 1988. Urbanisation in the developing world. New York: Routledge.

Trancik, R., 1986. Finding lost space: theories of urban design. New York: J. Wiley.

Yang, Y., 2010. Sustainable urban transformation - Driving forces, indicators and processes. PhD Thesis. ETH ZURICH, Zurich. 